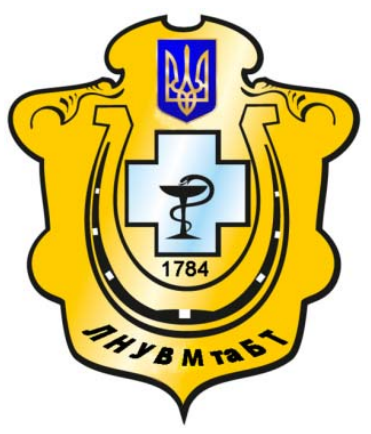

Науковий вісник Львівського національного університету ветеринарної медицини та біотехнологій імені С.3. Гжицького

Scientific Messenger of Lviv National University of Veterinary Medicine and Biotechnologies named after S.Z. Gzhytskyj

doi:10.15421/nvlvet7050

ISSN 2413-5550 print

ISSN 2518-1327 online

$\underline{\text { http://nvlvet.com.ua/ }}$

УДК 598.132.8

\title{
Морфологічні, культуральні та біохімічні властивості ізолятів бактерій, виділених з органів черепахи червоновухої
}

\author{
М.В. Скрипка ${ }^{1}$, П.І. Саулін ${ }^{1}$, I.I. Панікар ${ }^{1}$, О.В. Мачуський ${ }^{2}$ \\ pascha.saulin@yandex.ua, vetmed2010@ukr.net, vetbio84@gmail.com \\ ${ }^{1}$ Полтавська державна аграрна академія, \\ вул. Сковороди, 1/3, м. Полтава, 36000, Украӥна; \\ 2 Державний науково-контрольний інститут біотехнології і итамів мікроорганізмів, \\ вул. Донецька, 30. м. Київ, 03151, Украӥна
}

\begin{abstract}
У статті подані результати бактеріологічного дослідження n'яти червоновухих черепах. Первинні посіви зроблені із серия, печінки, нирок, селезінки та легень на загальновживані (МПБ і МПА) та селективні поживні середовища (агар Ендо, ксилозо-лізиновий дезоксіхолатний агар (XLD Agar), агар PALCAM, сольові бульйони із різною кониентрацією $\mathrm{NaCl}(2 \%, 5 \%$ та 10\%)). У результаті проведених бактеріологічних досліджень з організму черепахи червоновухої було виділено чотири ізоляти мікроорганізмів: два ізоляти із роду Staphylococcus, по одному із родів Klebsiella та Yеrsinia. Нами було встановлено, щзо итами Klebsiella рпеитопіае є високочутливі до іміпенему, меропенему, чутливі до амікацину, нетилміцину. Штами Yersinia enterocolitica, є чутливі до амоксициліну, ріфампіциину, пеніииліну та цефттриксону. Staphylococcus еріdermidis (№ 1, 2, 4, 5) штами були високочутливі до ванкоміцину та ріфампіщуину, чутливі до гатіфлоксаиину, лінезоліду. Дані штами отримали позначку PA-11/15. Staphylococcus epidermidis (№ 3) мав чутливість до метициліну. Дана різниия, на наш погляд, є принциповою, тому даний штам було виокремлено, та він отримав позначку Роltava-15. Ураховуючи, щуо виділені ізоляти Klebsiella pneumoniae та Yersinia enterocolitica є патогенними для організму людини, і особливо чутливі до даних збудників діти, вважаємо за необхідне проводити моніторинг бактеріального фону тварин у зоомагазинах та на ринках.

Ключові слова: рептилії, патоген, черепаха червоновуха, итам, ізоляти, культивування, мікроорганізм, поживне середовище, Staphylococcus epidermidis, Klebsiella pneumoniae, Yersinia enterocolitica.
\end{abstract}

\section{Морфологические, культуральные и биохимические свойства изолятов бактерий, выделенных из органов красноухой черепахи}

\author{
М.В. Скрипка ${ }^{1}$, П.И. Саулин ${ }^{1}$, И.И. Паника ${ }^{1}$, А.В. Мачуський${ }^{2}$ \\ pascha.saulin@yandex.ua, vetmed2010@ukr.net, vetbio84@gmail.com \\ ${ }^{1}$ Полтавская государственная аграрная академия, \\ ул. Сковороды, 1/3, м. Полтава, 36000, Украина; \\ ${ }^{2}$ Государственный научно-контрольный институт биотехнологии и штаммов микроорганизмов, \\ ул. Донеикая, 30 м. Киев, 03151, Украина
}

В статье представлены результаты бактериологического исследования пяти красноухих черепах. Первичные посевы сделаны из сердиа, печени, почек, селезенки и легких на общеупотребительные (МПБ и МПА) и селективные питательные среды (агар Эндо, ксилозо-лизиновый дезоксихолатный агар (XLD Agar), агар PALCAM, солевые бульоны с различной концентрацией $\mathrm{NaCl}(2 \%, 5 \%$ и 10\%)). В результате проведенных бактериологических исследований из организма черепахи красноухой было выделено четыре изоляты микроорганизмов: два изоляты из рода Staphylococcus, по одному из родов Klebsiella и Yersinia. Нами было установлено, что штаммы Klebsiella pпеитопіае являются высокочувствительны к имипенему, меропенему, чувствительны к амикацину, нетилмицину. Штаммы Yersinia enterocolitica, чувствительны к амоксицилину,

\section{Citation:}

Skripra, M., Saulin, P., Panikar, I., Machuskyy, O. (2016). The morphological, cultural and biochemical properties of isolates of bacteria isolated from the shell of Red-eared slider's. Scientific Messenger LNUVMBT named after S.Z. Gzhytskyj, 18, 3(70), $210-214$. 
рифампицину, пенициллину и иефтриаксону. Staphylococсия еріdermidis (№ 1, 2, 4, 5) итаммы были высокочувствительныл к ванкомицину и рифампицину, чувствительные к гатифлоксацину, линезолиду. Даннье штаммы получили отметку РА11/15. Staphylococcus epidermidis (№ 3), имел чувствительность к метициллину. Данная разница на наши взгляд, является принципиальной, поэтому данный штамм был выделен, и он получил отметку Роltava-15. Учитьвая, что вылеленные изоляты Klebsiella pneuтопіае и Yersinia enterocolitica являются патогенньми для организма человека, и особенно чувствительны к данным возбудителям дети, считаем необходимым проводить мониторинг бактериального фона животных в зоомагазинах и на рынках.

Ключевые слова: рептилии, патоген, красноухая черепаха, итамм, изоляты, культивирование, микроорганизм, питательная среда, Staphylococcus epidermidis, Klebsiella pneumoniae, Yersinia enterocolitica.

\title{
The morphological, cultural and biochemical properties of isolates of bacteria isolated from the shell of Red-eared slider's
}

\author{
M. Skripra ${ }^{1}$, P. Saulin ${ }^{1}$, I. Panikar ${ }^{1}$, O. Machuskyy ${ }^{2}$ \\ pascha.saulin@yandex.ua, vetmed2010@ukr.net, vetbio84@gmail.com \\ ${ }^{1}$ Poltava state agrarian academy, Skovoroda Str., 1/3, Poltava, 36000, Ukraine \\ ${ }^{2}$ State scientific control institute of biotechnology and strains, Donetsk Str., 30, Kyiv, 03151, Ukraine
}

The article presents the results of bacteriological tests of five Red-eared slider's (Trachemys scripta elegans') organs. Primary inoculations were made from heart, liver, kidney, spleen and lung on commonly used (beef-extract agar-agar and beef-extract broth) and selective culture medium (Endo agar, Xylose-Lysine Deoxycholate agar (XLD Agar), agar PALCAM, salt broths with varying concentrations of $\mathrm{NaCl}(2 \%, 5 \%$ and 10\%)). Because of bacteriology tests from Red-eared slider's (Trachemys scripta elegans') organisms there were excreted four microorganisms' isolates: two Staphylococcus isolates, and one of Klebsiella and one of Yersinia. We have found that strains of Klebsiella pneumoniae is highly sensitive to imipenem, meropenem, sensitive to amikacin, netilmicin. Strains of Yersinia enterocolitica are sensitive to amoxicillin, rifampicin, penicillin and ceftriaxone. Staphylococcus epidermidis (No. 1, 2, 4, 5) strains were highly sensitive to vancomycin and rifampicin, sensitive to gatifloxacin, linezolid. These strains have received PA-11/15 mark. Staphylococcus epidermidis (No. 3) had a sensitivity to methicillin. This difference in our opinion is fundamental, therefore, this strain was isolated and it received Poltava-15 mark. Taking into account that the isolates of Klebsiella pneumoniae and Yersinia enterocolitica selected are pathogenic for the human body and children are particularly sensitive to these pathogens, we consider it necessary to monitor the bacterial background of animals in pet shops and markets.

Key words: reptile, pathogen, strain isolates, cultivating microorganism nutrient sulfur-ment, Staphylococcus epidermidis, Klebsiella pneumoniae, Yersinia enterocolitica.

\section{Вступ}

В останні роки широкої популярності набуває розведення та утримання різних видів рептилій, які приваблюють людей своєю екзотичністю та примарною невибагливістю. Господарі облаштовують вдома тераріуми, однак тільки деякі з них створюють необхідні умови для утримання цих екзотичних тварин (Podschun and Ullmann, 1998).

За своєю фізіологією більшість рептилій можуть бути носіями інфекційних агентів, які становлять загрозу людині. Отже моніторинг мікробного фону організму цих тварин та дослідження клінікоморфологічного прояву захворювань різної етіології $\epsilon$ важливим для своєчасної діагностики та лікування тварин, проведення профілактичних заходів і запобігання контамінації навколишнього середовища та організму людей патогенними та умовно-патогенними мікроорганізмами (Kocjumbas et al., 2012).

Актуальність теми: хвороби бактеріальної етіології займають одне з провідних місць серед усіх захворювань черепах. Знання інфекційних хвороб плазунів необхідно для людей, що мають безпосередній контакт з ними. I не тільки тому, що вони найбільш поширені, як зазначено вище, але і тому, що деякі збудники цих хвороб викликають або можуть викликати подібні захворювання у людини (Kocjumbas et al., 2012).
У зоопарках, де черепахи утримуються великими группами, бактеріальні хвороби є причиною загибелі рептилій в $36 \%$ випадків і займають провідне місце серед усіх захворювань у неволі. Пов'язане це в першу чергу з тим, що в умовах неволі, а саме в замкнутому просторі тераріуму, умовно-патогенна грамнегативна мікрофлора клоаки швидко колонізує ротову порожнину і верхні дихальні шляхи черепах (Vasil'ev, 2003). Так, за даними Ярофке Д., (1998), із 40 проб десяти клінічно здорових черепах були ізольовано 179 бактеріальних культур, перш за все грамнегативні штами мікроорганізмів (Jarofke and Lange, 1998)

Так, наприклад, одним з основних компонентів нормальної мікрофлори шкіри як тварин, так і людей $\epsilon$ епідермальний стафілокок (Staphylococcus epidermidis), який у медичній практиці є досить розповсюдженим збудником лікарняних інфекцій. Розповсюдженість даного виду бактерій обумовлена не так вірулентністю, як великою кількістю сприятливих хворих з ослабленим імунітетом. Не зважаючи на низьку вірулентність, збудник сприяє швидкому розповсюдженню ентерококів. Епідермальний стафілокок має низьку вірулентність, лікування викликаних ним інфекцій часто буває складним, так як більшість штамів стійкі до широко розповсюджених антибіотиків. Стафілококи стійкі не тільки до бензилпеніциліну, але і до напівсинтетичних пеніцилінів, цефалоспоринів, а часто і до антибіотиків інших груп. 
Клебсієла, або паличка Фрідлендера (Klebsiella pneumoniae) - вид грамнегативних факультативноанаеробних паличковидних бактерій, що відіграє не останню роль у виникненні пневмоній та асоційованих інфекцій сечостатевої системи (Connell et al., 2007). Крім того, даний збудник у процесі своєї життєдіяльності в інфікованому організмі призводить до утворення гнійних абсцесів печінки, селезінки, викликає гнійні фібринозні плеврити, перикардити, гайморити, ендофтальміти (Podschun and Ullmann, 1998). У черепах даний збудник може викликати хронічний риніт (Vasil'ev, 2003).

Деякі штами мають полірезистентність до антибіотиків, обумовлену наявністю R-плазміди (Livrelli et al., 1996), а також стійкі до карбопенемів за рахунок наявності карбопенем-гідролізуючих $\beta$-лактамаз (Podschun and Ullmann, 1998; Livrelli et al., 1996). He останню роль у вірулентності відіграє капсула мікроорганізму (Vasil'ev, 2003).

Ще один представник сімейства ентеробактерій Yersinia. Ентеропатогенні ієрсинії широко розповсюджені, але частіше їх виділяють в країнах з помірним або субтропічним кліматом. Головним резервуаром $Y$. pseudotuberculosis в природі є гризуни (миші, щури, зайці, кролики) і дика птиця. Ці мікроби можуть довго зберігатися у грунті і річковій воді. Мікроорганізми виду Y. enterocolitica виділяють від багатьох теплокровних тварин (диких, домашніх, сільськогосподарських), рідше - від рептилій, риб або молюсків. Хоча непатогенні Y. enterocolitica біовару 1А частіше зустрічаються в об'єктах зовнішнього середовища, збудники ієрсиніозу теж можуть досить довго зберігатися в них, створюючи загрозу передачі інфекції в разі контамінації води, грунту, рослин, продуктів харчування (Smirnov, 1996).

За даними Орєхової Г. А., (2015) основними вхідними воротами інфекції за ієрсиніозу і псевдотуберкульозу є шлунково-кишковий тракт (Orehova, 2015). У той же час Івановська Л.Б. (2007) зазначає, що інфікування відбувається і через кров (у випадку с Yersinia pestis) або через стравохід (Yersinia pseudotuberculosis) при споживанні заражених продуктів (особливо овочів, молока й м'яса) (Antonov et al, 1986).

Метою нашої роботи було дослідити бактеріальний фон черепахи червоновухої із визначенням чутливості до антибактеріальних препаратів виділених культур.

\section{Матеріал і методи досліджень}

Досліди з тваринами поводилися відповідно до «Європейської конвенції про захист хребетних тварин, що використовуються для дослідних та інших наукових цілей», Страсбург, від 18 березня 1986 року.

У дослід було залучено 5 черепах червоновухих (Trachemys scripta elegans). Відбір патологічного матеріалу проводили за загально прийнятими методиками (Ivanovs'ka, 2007). Первинні посіви робили із серця, печінки, нирок, селезінки та легень на загальновживані (МПБ і МПА) та селективні поживні середовища (агар Ендо, ксилозо-лізиновий дезоксіхолатний агар (XLD Agar), агар PALCAM, сольові бульйони із різною концентрацією $\mathrm{NaCl}(2 \%, 5 \%$ та $10 \%)$, що готували за загальноприйнятими методиками (Golovko et al., 2007).

Вивчення морфологічних властивостей ізолятів здійснювали шляхом виготовлення мазків 3 добових бульйонних та агарових культур, їх фарбуванням та дослідженням методом світлової мікроскопії, використовуючи збільшення мікроскопу $\times 1000$. Фарбування проводили за Грамом, Ольтом та РомановськимГімза. Під час дослідження звертали увагу на форму клітин, їх сполучення і розміри, здатність до утворення спор та капсул, а також рухливість.

Для вивчення культуральних властивостей мікроорганізми культивували в рідких та на щільних поживних середовищах за температури $37 \pm 1^{\circ} \mathrm{C}$ протягом 18 - 24 годин, при цьому звертали увагу на помутніння середовища, наявність осаду, плівок, пластівців, ниток та пристінкового кільця тощо.

Біохімічні властивості ізольованих мікроорганізмів вивчали шляхом їх інкубування за температури $37 \pm 1^{\circ} \mathrm{C}$ протягом 48 годин на середовищах Гісса 3 додаванням арабінози, целлобіози, ескуліну, галактози, лактози, мальтози, маннітолу, маннози, мелецитози, мелібіози, рафінози, рибози, саліцину, сорбіту, цукрози, трегалози, ксилози, рамнози, D-глюкози, дульциту та інозиту.

Контроль поживних середовищ на стерильність проводили шляхом їх інкубування в термостаті за температури $37 \pm 1{ }^{\circ} \mathrm{C}$ протягом 48 годин.

Контроль поживних середовищ за ростовими властивостями проводили відповідно до ДСТУ ISO $\backslash$ TS 11133-1:2000 IDT «Мікробіологія харчових продуктів i кормів для тварин. Настанови щодо готування і виробництва поживних середовищ» частини 1 та 2. При цьому використовували еталонні тест-культури Національного центру штамів мікроорганізмів.

Антибіотикочутливість виділених ізолятів визначали диск-дифузійним методом на щільних поживних середовищах.

Для довготривалого збереження виділених ізолятів застосовували метод сублімаційного висушування в апараті LP-3 фірми TelStar (Іспанія). Ліофілізацію проводили відповідно до «Методических рекомендаций по разработке режимов замораживаниявысушивания биологических препаратов», (1981), 3 використанням захисного середовища Файбіча (Nikitin and Zvjagin, 1971).

\section{Результати та їх обговорення}

У результаті проведених досліджень 3 патологічного матеріалу від черепах було виділено 4 ізоляти мікроорганізмів (табл. 1).

За тінкториальними, морфологічним та культуральними властивостями п'ять 3 них було віднесено до роду Staphylococcus, два до роду Klebsiella та три - до Yersinia.

Із легень черепах № 2 та № 4 було ізольовано мікроорганізм, який в рідкому поживному середовищі після культивування утворював ріст у вигляді помутніння з наявністю тягучого слизистого осаду і плівки; 
на щільному поживному середовищі ріс у вигляді круглих слизових сіро-білих колоній. Бактерії під мікроскопом виглядали як прямі палички розміром $0,3-1,0 \times 0,6-6,0$ мкм, за Грамом клітини фарбувалися негативно. Розміщені в мазках поодиноко, у парі та коротких ланцюжках. Палички нерухливі. Культура каталазопозитивна та оксидазонегативна, ферментувала з утворенням кислоти і газу глюкозу, з утворенням кислоти арабінозу, інозит, ксилозу, лактозу, мальтозу, маніт, рамнозу, рафінозу, сорбіт, сахарозу, маннозу, гідролізувала сечовину та ескулін, не гідролізувала желатину, не ферментувала дульцит. За вищеперерахованими характеристиками ізолят було ідентифіковано як Klebsiella pneumoniae (DeVos et al., 2009), штам отримав позначку $S P-15$ та є високочутливим до іміпенему, меропенему, чутливий до амікацину, нетилміцину, нечутливий до гентаміцину, ципрофлоксацину, цефтриаксону.

Результати бактеріологічного дослідження патологічного матеріалу від черепах

\begin{tabular}{|c|c|c|c|c|c|}
\hline Тварина & Серце & Печінка & Легені & $\begin{array}{c}\text { Контроль } \\
\text { позитивний }\end{array}$ & $\begin{array}{c}\text { Контроль } \\
\text { негативний }\end{array}$ \\
\hline Черепаха №1 & $\begin{array}{c}\text { Staphylococcus } \\
\text { epidermidis }\end{array}$ & $\begin{array}{c}\text { Yersinia } \\
\text { enterocolitica }\end{array}$ & - & + \\
\hline Черепаха №2 & $\begin{array}{c}\text { Staphylococcus } \\
\text { epidermidis }\end{array}$ & - & $\begin{array}{c}\text { Klebsiella } \\
\text { pneumoniae }\end{array}$ & + & - \\
\hline Черепаха №3 & $\begin{array}{c}\text { Staphylococcus } \\
\text { epidermidis }\end{array}$ & $\begin{array}{c}\text { Yersinia } \\
\text { enterocolitica }\end{array}$ & - & + & - \\
\hline Черепаха №4 & $\begin{array}{c}\text { Staphylococcus } \\
\text { epidermidis }\end{array}$ & - & $\begin{array}{c}\text { Klebsiella } \\
\text { pneumoniae }\end{array}$ & + & - \\
\hline Черепаха №5 & $\begin{array}{c}\text { Staphylococcus } \\
\text { epidermidis }\end{array}$ & $\begin{array}{c}\text { Yersinia } \\
\text { enterocolitica }\end{array}$ & - & + & - \\
\hline
\end{tabular}

Із печінки черепах № 1, № 3 та № 5 було ізольовано мікроорганізми, яків рідкому поживному середовищі після культивування протягом 24 годин за температури $37{ }^{\circ} \mathrm{C}$ росли у вигляді помутніння; на щільному поживному середовищі росли у вигляді дрібних блискучих колоній S-форми з блакитним відтінком, на агарі Ендо - колонії були рожевого відтінку. Колонії під мікроскопом виглядали як прямі палички діаметром 0,5-0,8 та довжиною 1- 3 мкм, спор та капсул не утворювали, за Грамом клітини фарбувалися негативно. Палички рухливі за температури $20{ }^{\circ} \mathrm{C}$. Культури каталазопозитивні та оксидазонегативні, ферментували з утворенням кислоти глюкозу, арабінозу, гліцерол, мальтозу, маніт, маннозу, сахарозу, сорбіт, гідролізували сечовину та не гідролізували желатину, не ферментували дульцит, інозит, ксилозу, лактозу, рамнозу, рафінозу.

За вище перерахованими характеристиками ізоляти було ідентифіковано як Yersinia enterocolitica (DeVos et al., 2009), штами отримали позначку - 11/15 та $\epsilon$ чутливі до амоксициліну, ріфампіцину, пеніциліну та цефтриаксону.

Із серця усіх п’яти тварин було виділено мікроорганізм, що в рідкому поживному середовищі після культивування протягом 24 годин за температури $37^{\circ} \mathrm{C}$ утворювали ріст у вигляді помутніння з наступним утворенням осаду у вигляді пластівців; на щільному поживному середовищі росли у вигляді круглих білих колоній 3 рівними краями. При цьому колонії під мікроскопом були у вигляді сферичної форми діаметром 0,5 - 1,5 мкм, за Грамом клітини фарбувалися позитивно. У мазках розміщувалися поодиноко, у парі та групах неправильної форми, нерухливі. Культури каталазопозитивні та оксидазонегативні, ферментували з утворенням кислоти сахарозу, мальтозу, маннозу, лактозу, мальтозу, не ферментували ксилозу, арабінозу, рафінозу, саліцин, маніт.
За вище перерахованими характеристиками ізоляти було ідентифіковано як Staphylococcus epidermidis (DeVos et al., 2009). Але у черепах № 1, № 2, № 4 та № 5 штами були високочутливі до ванкоміцину та ріфампіцину, чутливі до гатіфлоксацину, лінезоліду, нечутливі до пеніциліну, амоксициліну, метициліну. Дані штами отримали позначку $P A-11 / 15$.

У черепахи № 3 виділений Staphylococcus epidermidis вирізнявся чутливістю до метициліну, а саме - був до нього чутливим. Дана різниця, на нашу думку є принциповою, тому даний штам було виокремлено та він отримав позначку Poltava-15.

Усі вище описані мікроорганізми було паспортизовані та депоновані в Національному центрі штамів мікроорганізмів Державного науково-контрольного інституту біотехнології і штамів мікроорганізмів: Klebsiella pneumoniae SP-15 - депозитарний номер 670, Yersinia enterocolitica PI-11/15- депозитарний номер 669, Staphylococcus epidermidis PA-11/15 - депозитарний номер 668 та Staphylococcus epidermidis Poltava-15 - депозитарний номер 667.

Враховуючи, що виділені з організму черепахи червоновухої ізоляти Klebsiella pneumoniae та Yersinia enterocolitica $є$ патогенними для організму людини, відповідно, слід проводити роз'яснювальну роботу щодо дотримання правил безпеки життєдіяльності серед обслуговуючого персоналу зоопарків та робітників зоомагазинів. Крім того, є потреба в проведенні діагностичних досліджень черепах на наявність збудників даних захворювань 3 метою попередження інфікування потенційних покупців, а в першу чергу дітей.

\section{Висновки}

1. У результаті проведених бактеріологічних досліджень з організму черепахи червоновухої було виділено чотири ізоляти мікроорганізмів: два ізоляти із 
роду Staphylococcus, по одному із родів Klebsiella та Yersinia.

2. Штами Klebsiella pneumoniae є високочутливими до іміпенему, меропенему, чутливі до амікацину, нетилміцину. Штами Yersinia enterocolitica є чутливими до амоксициліну, ріфампіцину, пеніциліну та цефтриаксону. Staphylococcus epidermidis (№ 1, 2, 4, 5) штами були високочутливі до ванкоміцину та ріфампіцину, чутливі до гатіфлоксацину, лінезоліду. Staphylococcus epidermidis (№ 3), мав чутливість до метициліну.

Перспективи подальших досліджень: подальше дослідження морфологічного стану організму за вище зазначеного мікробного статусу та чутливості лабораторних тварин до виділених ізолятів мікроорганізмів. На підставі вивчення чутливості виділених мікроорганізмів до антибактеріальних препаратів та характеру ураження внутрішніх органів рептилій - розробити i впровадити нові методи діагностики та лікування домашніх рептилій.

\section{Бібліографічні посилання}

Kocjumbas, G.I., Dankovych, R.S., Strons'kyj, Ju. S. ta in. (2012). Hvoroby reptylij ta i'h patomorfologichna diagnostyka. Navchal'nyj posibnyk. L'viv: Vydavnycha firma «Afisha» (in Ukrainian)

Vasil'ev, D.B. (2003). Cherepahi. Bolezni i lechenie M., «AKVARIUM LTD», K.:FGUIPPV (in Russian)

Jarofke, D., Lange, J. (1998). Cherepahi, jashhericy, zmei. M.: Akvarium (in Russian)

Connell, N.T., Thomas, I.A., Sabharwal, A.D. and Gelbard, M.A. (2007). Klebsiella pneumoniae eendophthalmitis with associated hepatic abscess. J. Hosp. Med., 2, 442-444.
Podschun R., Ullmann U. (1998). Klebsiella spp. as nosocomial pathogens: Epidemiology, taxonomy, typing methods, and pathogenicity factors. Clin. Microbiol. Rev. 11, 589-603.

Livrelli, V., de Champs, C., di Martino, P., DarfeuilleMichaud, A. (1996). Adhesive properties and antibiotic resistance of Klebsiella, Enterobacter, and Serratia clinical isolates involved in nosocomial infections. J. Clin. Microbiol, 34.

Smirnov, I.V. (1996). Verifikacionnye metody mikrobiologicheskoj diagnostiki iersinioza i psevdotuberkuleza. Rjazan': RjazGMU (in Russian)

Orehova, G.A. (2015). Kyshkovyj ijersinioz tvaryn (aktual'nist', epizootologija, diagnostyka, ogljad literatury). Veterynarna medycyna. 101, 125-129 (in Ukrainian)

Ivanovs'ka, L.B. (2007). Epizootologichnyj monitoryng ta rozrobka serologichnoi' diagnostyky ijersyniozu tvaryn: avtoref. dys. kand. vet nauk: 16.00.08/ Ivanovs'ka L.B. Instytut eksperymental'noi' i klinichnoi' veterynarnoi' medycyny. Harkiv, 26 (in Ukrainian)

Antonov. B.I., Borisova. V.V., Volkova. P.M. i dr. (1986). Laboratornye issledovanija V veterinarii. Spravochnik. Bakterial'nye infekcii. M.: Agropromizdat (in Russian)

Golovko, A.N. i dr. (2007). Mikrobiologicheskie i virusologicheskie metody issledovanij $\mathrm{v}$ veterinarnoj medicine: spravoch. posob. H.: NTMT, 365-372 (in Russian)

Nikitin, E.E., Zvjagin, I.V. (1971). Zamorazhivanie i vysushivanie biologicheskih preparatov. M.: Kolos (in Russian)

DeVos, P. (2009). Bergey's Manual of Systematic Bacteriology. 2-nd ed. London, NewYork: Springer, 3, 144257.

Стаття надійшла до редакиії 3.10.2016 